\title{
Erratum to: Human and ecotoxicological impacts assessment from the Mexican oil industry in the Coatzacoalcos region, as revealed by the USEtox ${ }^{\mathrm{TM}}$ model
}

\author{
M. A. Morales-Mora • B. Rodríguez-Pérez • \\ S. A. Martínez-Delgadillo • E. Rosa-Domínguez • \\ C. Nolasco-Hipólito
}

Published online: 6 September 2014

(C) Springer-Verlag Berlin Heidelberg 2014

Erratum to: Environ Sci Pollut Res

DOI 10.1007/s11356-014-2942-4

The original publication of this article contains a mistake. The figure that indicate to be number 3 correspond in fact to figure number 4 and vice versa; the figure that indicate to be number 4 , correspond to figure number 3 .

The online version of the original article can be found at http://dx.doi.org/ 10.1007/s11356-014-2942-4.

M. A. Morales-Mora $(\square)$

Subgerencia de Protección Ambiental, PEMEX-Petroquímica,

Jacarandas 100, Colonia Rancho Alegre, Coatzacoalcos,

Veracruz 96558, México

e-mail: miguel.angel.moralesmo@pemex.com

B. Rodríguez-Pérez

Industrial Engineering Department, University of Cienfuegos,

Carretera a Rodas 4, Caminos, Cienfuegos 55200, Cuba

e-mail: brguez@ucf.edu.cu

\section{S. A. Martínez-Delgadillo}

Universidad Autónoma Metropolitana, Azcapotzalco,

Avenida San Pablo 180, Azcapotzalco, Mexico

e-mail: samd@correo.azc.uam.mx

E. Rosa-Domínguez

Chemistry-Pharmacy Faculty, Central University Marta Abreu de

Las Villas, Camajuaní Road km 5ํㅡㄹ, Santa Clara, Villa Clara 54830,

Cuba

e-mail: erosa@uclv.edu.cu

C. Nolasco-Hipólito

Faculty of Resource Science and Technology, University Malaysia

Sarawak, Kota Samarahan 94300, Malaysia

e-mail: hcnolasco@frst.unimas.my 